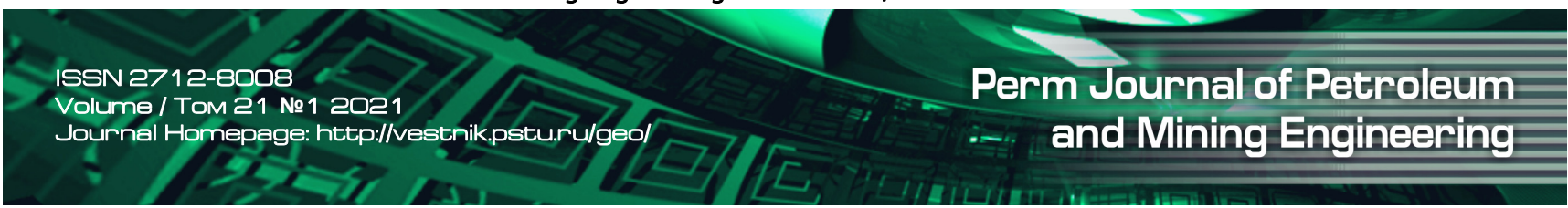

UDC 666.321.019

Article / Статья

( ) PNRPU / ПНИПУ, 2020

\title{
Formation of the Kaolin Structure Treated by Pressure
}

Valerii V. Seredin ${ }^{1}$, Andrey V. Andrianov ${ }^{1}$, Sharibzan Kh. Gaynanov ${ }^{1}$, Vladislav I. Galkin ${ }^{2}$, Sergey S. Andreyko ${ }^{2}$

${ }^{1}$ Perm State National Research University (15 Bukireva st., Perm, 614068, Russian Federation)

${ }^{2}$ Perm National Research Polytechnic University (29 Komsomolskiy av., Perm, 614990, Russian Federation)

\section{Формирование структуры каолина, обработанного давлением}

\section{В.В. Середин ${ }^{1}$, А.В. Андрианов ${ }^{1}$, Ш.Х. Гайнанов ${ }^{1}$, В.И. Галкин ${ }^{2}$, С.С. Андрейко ${ }^{2}$}

${ }^{1}$ Пермский государственный национальный исследовательский университет (Россия, 614068, г. Пермь, ул. Букирева, 15) ${ }^{2}$ Пермский национальный исследовательский политехнический университет (Россия, 614990, г. Пермь, Комсомольский пр., 29)

\section{Received / Получена: 23.07.2020. Accepted / Принята: 02.11.2020. Published / Опубликована: 11.01.2021}

Keywords:

clay, kaolin, pressure, structure, defectiveness, chemical composition, ionic bonds, structural package defects, mineral, colloid, aggregate, technogenic processing, clay activation.

Ключевые слова: глина, каолин, давление, структура, дефектность, химический состав, ионные связи, дефекты структурного пакета, минерал, коллоид, агрегат, техногенная обработка, активация глин.
To form the technological properties of clays, various methods of their activation have been developed, the essence of which is that when processing clays, their structure (defectiveness) changes, which forms the energy potential of clay particles, and the latter is realized in the form of "specified" physicochemical properties of clays. In this regard, the effect of stress pressure on the change in the defectiveness of structural elements of kaolin was studied.

Experimental studies showed that the pressure value $P=150 \mathrm{MPa}$ was the boundary value at which different conditions for the formation of defectiveness of structural elements of kaolin were observed. High pressure has a multidirectional effect on the defectiveness formation of the kaolin structural elements: a package, a mineral, a colloid and an aggregate.

In a package of kaolinite mineral, the defectiveness increases with increasing pressure. Defects are formed due to the removal of $\mathrm{Al}$, Fe, Mg, Si ions from the octahedral and tetrahedral sheets. Al ions are the most sensitive to pressure. The removal of ions entails deformation of the packet and the formation of "hole" energy centers. Pressure up to 0-150 MPa has a greater effect on the formation of defectiveness (calculated correlation coefficient $\left.r_{c}=0.86\right)$ than in the range 150-800 MPa $\left(r_{c}=0.82\right)$. In the kaolinite mineral at pressures up to $150 \mathrm{MPa}$, a decrease in defectiveness is observed due to the ordering of the structure under pressure $\left(r_{c}=0.67\right)$. At pressures above $150 \mathrm{MPa}$, an increase in the defectiveness of the kaolinite mineral $\left(r_{c}=-0.72\right)$ is observed due to the destruction of hydrogen bonds between the packets, which entails the sliding and rotation of the structural packets among themselves.

In a colloid (particle), with an increase in pressure to $150 \mathrm{MPa}$, the structural defect decreases due to an increase in the colloid density $\left(r_{c}=0.67\right)$. In the pressure range of $150-800 \mathrm{MPa}$, it is rather difficult to reveal the effect of pressure on the formation of defectiveness $(\mathrm{rc}=0.37)$.

In the aggregate, with an increase in pressure to $150 \mathrm{MPa}$, the defectiveness of the structure increases due to crushing of particles, sliding and displacement of particles among themselves $\left(r_{c}=0.95\right)$. In the pressure range of 150-800 MPa, it is rather difficult to reveal the influence of pressure on the formation of defectiveness $\left(r_{c}=0.58\right)$, although the tendency increases with increasing pressure, the defectiveness of the aggregate remains.

Для формирования технологических свойств глин разработаны различные способы их активации, суть которых заключается в том, что при обработке глин изменяется их структура (дефектность), которая формирует энергетический потенциал глинистых частиц, а последний реализуется в виде «заданных» физико-химических свойств глин. В связи с этим изучено влияние стрессового давления на изменение дефектности структурных элементов каолина.

Экспериментальные исследования показали, что значение давления $P=150$ МПа является граничным, при котором наблюдаются различные условия формирования дефектности структурных элементов каолина. Высокое давление оказывает разнонаправленное воздействие на формирование дефектности структурных элементов каолина: пакета, минерала, коллоида и агрегата.

В пакете минерала каолинита с увеличением давления дефектность возрастает. Дефекты формируются за счет выноса из октаэдрического и тетраэдрического листов ионов $\mathrm{Al}, \mathrm{Fe}, \mathrm{Mg}, \mathrm{Si}$. Наиболее чувствительными к давлению являются ионы Al. Вынос ионов влечет за собой деформации пакета и формирование «дырочных» энергетических центров. Давление до 0-150 МПа оказывает большее влияние на формирование дефектности $\left(r_{p}=0,86\right)$, чем в интервале $150-800$ МПа $\left(r_{p}=0,82\right)$

В минерале каолините при давлениях до 150 МПа наблюдается уменьшение дефектности за счет упорядочивания структуры под давлением $\left(r_{p}=0,67\right)$. При давлениях больше 150 МПа наблюдается увеличение дефектности минерала каолинита $\left(r_{p}=-0,72\right)$ за счет разрушения водородных связей между пакетами, что влечет за собой скольжение и вращение структурных пакетов между собой.

В коллоиде (частице) при увеличении давления до 150 МПа дефектность структуры уменьшается за счет увеличения плотности коллоида $\left(r_{p}=0,67\right)$. В диапазоне давления 150-800 МПа выявить влияние давления на формирование дефектности достаточно сложно $\left(r_{p}=0,37\right)$.

В агрегате при увеличении давления до 150 МПа дефектность структуры возрастает за счет дробления частиц, скольжения и смещения частиц между собой $\left(r_{p}=0,95\right)$. В диапазоне давления 150-800 МПа выявить влияние давления на формирование дефектности достаточно сложно $\left(r_{p}=0,58\right)$, хотя тенденция с ростом давления возрастает, дефектность агрегата сохраняется.

Valerii V. Seredin (Author ID in Scopus: 56974744000) - Professor, Doctor in Geology and Mineralogy, Head of the Department of Engineering Geology and Subsoil Protection (tel.: + 00791298883 09, e-mail: seredin@ @edra.perm.ru). The contact person for correspondence.

Andrey V. Andrianov (Author ID in Scopus: 57143872200) - PhD Student at the Department of Engineering Geology and Subsoil Protection (tel.: + 00734221151 55, e-mail: Andrianov@nedra.perm.ru). Sharibzan Kh. Gaynanov - PhD in Geology and Mineralogy, Associate Professor at the Department of Engineering Geology and Subsoil Protection (e-mail: seredin@nedra.perm.ru).
Vladislav I. Galkin (Author ID in Scopus: 55418067700) - Doctor in Geology and Mineralogy, Professor, Head of the Department of Oil and Gas Geology (tel.: + 00790247295 81, e-mail: vgalkin@pstu.ru).

Sergey S. Andreyko (Author ID in Scopus: 55922205900 (Andreyko), 6506180352 (Andreiko)) - Doctor of Engineering, Professor, Head of the Department of Development of Mineral Recourses Fields (tel.: +007 91288243 93, e-mail: rmpi@pstu.ru).

Середин Валерий Викторович - профессор, заведующий кафедрой инженерной геологии и охраны недр, доктор геолого-минералогических наук (тел.: + 00791298883 09, e-mail: seredin@nedra.perm.ru). Контактное лицо для переписки.

Андрианов Андрей Владимирович - аспирант кафедры инженерной геологии и охраны недр (тел.: + 00734221151 55, e-mail: Andrianov@nedra.perm.ru).

Гайнанов Шарибзан Хатинович - доцент, кафедры инженерной геологии и охраны недр, кандидат геолого-минералогических наук (тел.: +007 3422115155 , e-mail: seredin@nedra.perm.ru).

Галкин Владислав Игнатьевич - профессор, заведующий кафедрой геологии нефти и газа, доктор геолого-минералогических наук (тел.: + 0079024729581 , e-mail: vgalkin@pstu.ru). Андрейко Сергей Семенович - профессор, заведующий кафедрой разработки месторождений полезных ископаемых, доктор технических наук (тел.: + 00791288243 93, e-mail: rmpi@pstu.ru).

Please cite this article in English as:

Seredin V.V., Andrianov A.V., Gaynanov S.Kh., Galkin V.I., Andreyko S.S. Formation of the Kaolin Structure Treated by Pressure. Perm Journal of Petroleum and Mining Engineering, 2021, vol.21, no.1, pp.9-16. DOI: 10.15593/2712-8008/2021.1.2

Просьба ссылаться на эту статью в русскоязычных источниках следующим образом: Ф.21, №1. - С.9-16. DOI: 10.15593/2712-8008/2021.1.2 


\section{Introduction}

Properties of clays are largely defined by their composition and structure $[1,2]$. There are various methods devised to activate clays that enhance their technological properties. In a nutshell, when clays are processed, it changes their structure (defectiveness) that shapes up the energy potential of clay particles, and this potential manifests itself as preset physicochemical properties of clays.

Namely, the studies found [3-5] that when clays are heated to $400-600{ }^{\circ} \mathrm{C}$ it unlocks high-energy centers on the surface of the mineral, which increases their adsorption activity. During UV-activation of clays [6] metal ions leave the octahedral positions due to the weakened bonds in the crystal lattice of minerals. This helps to increase the adsorption activity of clays by a factor of 1.3. Ultrasound treatment of clays destroys the aggregates and extends the crystal structure, which leads to higher absorption activity of clays [7, 8].

There are only a few studies that concern changes in defectiveness of pressurized kaolinite. The most detailed research of the matter was accomplished by A.G. Kossovskaya et al. back in 1963 [9], E.A. Goylo et al. in 1966 [10], K.J. Range et al. in 1969 [5], V.A. Frank-Kamenetsky et al. in 1970 and 1983 [11, 12], A. La Iglesia in 1993 [13], E. Galan et al. in 2006 [14]. Specifically, A. La Iglesia in 1993 [13] found that kaolin under pressures below $2000 \mathrm{MPa}$ fails to show any noticeable structure defectiveness changes, whereas at pressures over $4000 \mathrm{MPa}$ such changes do occur. Electron microscopy revealed that kaoline pressurized at $100-2000 \mathrm{MPa}$ is characterized by a large number of defects (cracks, bends, deformations, compacted layers, sheet slips and rotations, etc.). Fang et al. in 2017 [15] stated that pressures up to $0.600 \mathrm{GPa}$ break the structure of kaolin that gets restored at $66.2 \mathrm{GPa}$. When under pressure, the Al-O bond is weaker than $\mathrm{Si}-\mathrm{O}$, and the bond strength of the hydroxyl groups in kaolinite decreases as the pressure rises. The study of Welch et al. [16] in 2012 showed that kaolinite under pressure up to $9.5 \mathrm{GPa}$ undergoes polymorphic changes that are registered by IR spectroscopy $\left(v=3.595 \mathrm{~cm}^{-1}\right)$.

Works by E. Galan et al. in 2006 [14] proved that kaolin treated at pressures up to $1320 \mathrm{MPa}$ manifests structural changes and defects. At $400 \mathrm{MPa}$, the average number of layers (crystallites) grew from 25 to 36 . While researching kaolin at 1500-2300 MPa, E.A. Goylo [10] concluded that stress pressure is the main cause of its defectiveness. Similar conclusions were drawn by V.A. Frank-Kamenetsky et al. in 1970 and 1983 [11, 12], V.V. Boldyrev in 2006 [17], and others. When pressurized, kaolinite transforms, for instance, into dickite, potassium feldspar, etc. [18, 19]. The mentioned findings indicate that the nature of how pressure affects the defectiveness of kaolinite's structural package remains understudied. Therefore the purpose of this study is to investigate the influence of stress pressure on the changes in the defectiveness of kaolin structural elements.

\section{Methodology}

In terms of methodology, the research was conducted in the following order: at first, samples of kaolin clay rich in clay particles were subject to compression and displacement within the range of pressures from 0 to $800 \mathrm{MPa}$ following the procedure described by V.V. Seredin et al. in 2017 [20]. Then one group of samples was screened for their chemical composition using X-ray analysis [21], while the other group was studied for deformation and valency bonds between ions using IR-spectroscopy [22-24].

IR spectra were registered using the FT-IR spectrometer FSM 1201 made by Infraspec LLC in the range of 400$4000 \mathrm{~cm}^{-1}$ with resolution of $2 \mathrm{~cm}^{-1}$ (FT-IR) and Fspec software $[22,25]$.

The X-ray diffraction analysis was carried out according to V.A. Frank-Kamenetsky's technique [12].

\section{Study subjects}

The subject of the study is the kaolin clay rich in clay particles from the Chelyabinsk field. The grain size and mineral compositions of the natural and enriched clays are presented in Table 1.

\section{Effect of Pressure on Changes \\ in the Structural Package of Kaolinite}

Changes in the structure at the level of the pressurized kaolinite package can be caused by the removal and displacement of $\mathrm{Al}, \mathrm{Fe}, \mathrm{Mg}, \mathrm{Si}$ atoms that make up the octa- and tetrahedral sheets of kaolinite. To estimate the defectiveness in the structural package, pressurized kaolin was studied in terms of its chemical composition. The defectiveness caused by the displacement of atoms that make up the octa- and tetrahedral sheets of kaolinite was researched by means of IR spectroscopy.

Effect of Pressure on Changes in the Chemical Composition of Kaolin. The results of the bulk chemical composition of enriched kaolin clay are given in Table 2 .

As the data presented in Table 1 suggest, kaolin is mainly made up of $\mathrm{SiO}_{2}(59.48 \%), \mathrm{Al}_{2} \mathrm{O}_{3}(25.45 \%)$ and $\mathrm{Fe}_{2} \mathrm{O}_{3}(2.42 \%)$. The rest of the components are of minor importance.

Figure 1 demonstrates the results of experimental studies into the enriched kaolin clay exposed to stress pressure.

The retrieved data show that, as the pressure rises to $800 \mathrm{MPa}$, the oxide content of $\mathrm{Al}_{2} \mathrm{O}_{3}$ decreases correspondingly from 25.47 to $23.49 \%$, and $\mathrm{MgO}$, from 0.31 to $0.24 \%$. The content of $\mathrm{SiO}_{2}$ increases from 58.95 to $59.89 \%$, while the remaining oxides $\left(\mathrm{Fe}_{2} \mathrm{O}_{3}\right.$ and others) change diversely.

Table 1

Grain size and mineral compositions of kaolin

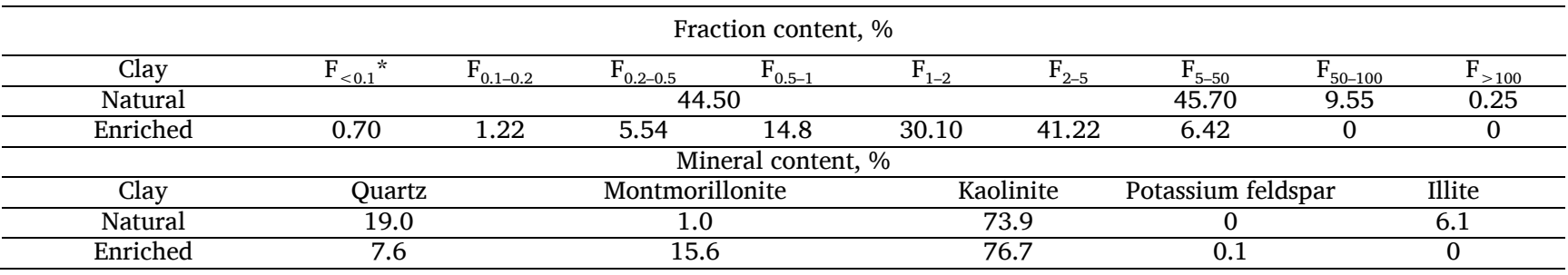

$\mathrm{N}$ o t e : Fraction size is given in micrometers. 
Chemical composition of enriched kaolin clay

\begin{tabular}{cccccccccccc}
\hline \multirow{2}{*}{ Clay } & \multicolumn{10}{c}{ Oxide, mass fraction, \% } \\
\cline { 2 - 26 } & $\mathrm{SiO}_{2}$ & $\mathrm{TiO}_{2}$ & $\mathrm{Al}_{2} \mathrm{O}_{3}$ & $\mathrm{Fe}_{2} \mathrm{O}_{3}$ & $\mathrm{MnO}$ & $\mathrm{CaO}$ & $\mathrm{MgO}$ & $\mathrm{Na}_{2} \mathrm{O}$ & $\mathrm{K}_{2} \mathrm{O}$ & $\mathrm{P}_{2} \mathrm{O}_{5}$ & $\begin{array}{c}\text { Other } \\
\text { impurities }\end{array}$ \\
\hline Enriched kaolin & 59.48 & 1.73 & 25.45 & 2.42 & 0.01 & 0.31 & 0.31 & 0.29 & 0.49 & 0.02 & 9.49 \\
\hline
\end{tabular}

Correlation coefficients

Table 3

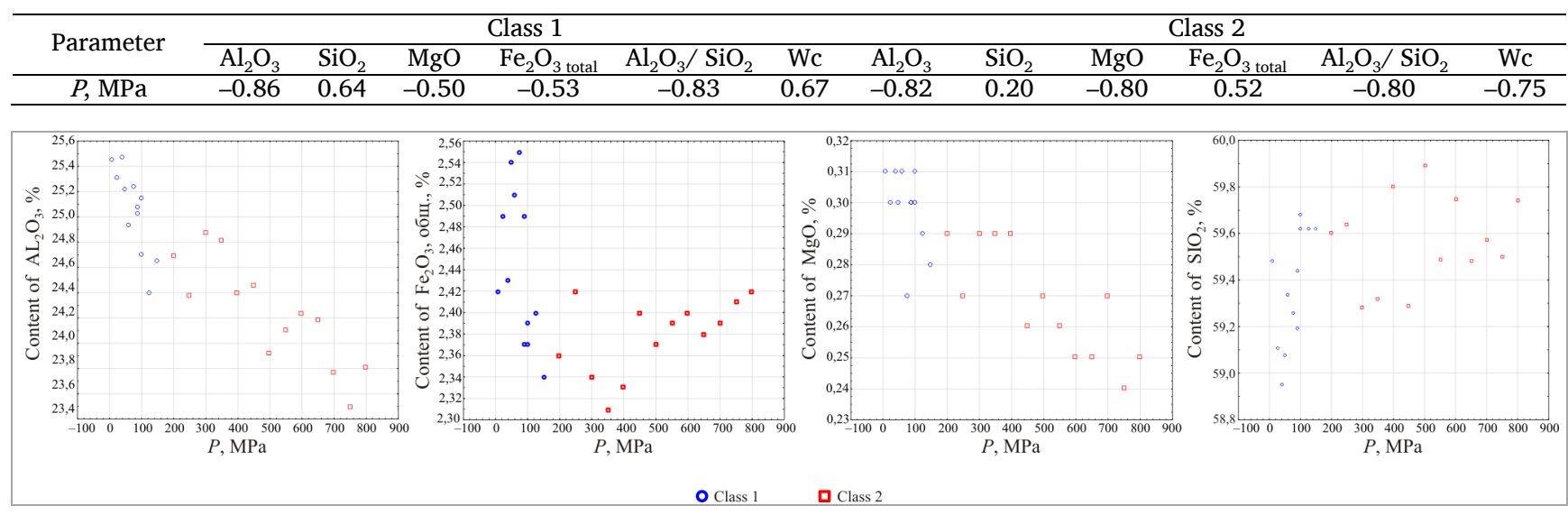

Fig. 1. Changes in the chemical composition of enriched kaolin clay exposed to stress pressure

The decrease of oxides $\mathrm{Al}_{2} \mathrm{O}_{3}$ is probably due to the removal of $\mathrm{Al}$ atoms from the octahedral lattice of kaolinite across the entire range of imposed pressures. The change in the content of $\mathrm{Fe}_{2} \mathrm{O}_{3}$ follows the same pattern: as pressure goes up to $150 \mathrm{MPa}$, ferric oxides drop. It can be interpreted as a removal of $\mathrm{Fe}$ atoms from the crystal lattice of kaolinite. The further increase in pressure from 150 to $800 \mathrm{MPa}$ brings up the content of Fe, which apparently has to do with the Fe atoms entering the crystal lattice of the mineral.

The increase in silicon oxides is probably triggered by the higher content of quartz [26] resulting from Si atoms in the tetrahedral lattice of kaolinite. Quartz may be generated when the clay is put under pressure up to $150 \mathrm{MPa}$, so that the octahedral sheet loses its $\mathrm{Al}$ atoms and the tetrahedral sheet loses Si atoms, which is in line with the findings of previous studies [27]. Since shell vacancies left by $\mathrm{Si}$ atoms have high energy, $\mathrm{Al}$ atoms fill them up while the free $\mathrm{Si}$ atoms enter into a reaction with oxygen atoms and make new tetrahedrons (quartz). At the same time the quartz content increases by $1 \%$.

Therefore, when stress pressure is exerted on kaolin clay, the structural package of kaolinite develops defects caused by the removal of $\mathrm{Al}, \mathrm{Fe}, \mathrm{Mg}$, ans $\mathrm{Si}$ atoms from the octahedral and tetrahedral sheets. The defects go by as "shell vacancies" formed by the removal of atoms from the crystal lattice and manifest themselves as "hole"-like energy centers that to a great extent define the physicochemical properties of kaolin [28, 29]. The atom removal triggers deformations in the crystal lattice of kaolinite.

To determine the influence of pressure on changes in the chemical composition of kaolinite, we used the correlation analysis that is based on the following principle: if stress pressure has a significant influence on the chemical composition, the estimated value of correlation coefficient $r_{p}$ will be higher than critical $r_{\mathrm{T}}$ obtained at $k=n^{-2}$ (degree of freedom) and $\alpha=0.05$ (degree of significance). The resulting matching correlation coefficients are presented in Table 3.

The data given in Table 3 show that in Class 1 ( $P=0-150 \mathrm{MPa}$ ) pressure significantly affects the changes in $\mathrm{Al}_{2} \mathrm{O}_{3}\left(r_{p}=-0.86>r_{\mathrm{T}}=0.34\right), \mathrm{MgO}\left(r_{p}=-0.50>r_{\mathrm{T}}=0.34\right)$, $\mathrm{Fe}_{2} \mathrm{O}_{3}\left(r_{p}=-0.53>r_{\mathrm{T}}=0.34\right)$ and $\mathrm{SiO}_{2}\left(r_{p}=0.64>r_{\mathrm{T}}=\right.$ $=0.34)$, i.e. the formation of defects in the octahedral and tetrahedral lattices of kaolinite. Class $2(P=150-800 \mathrm{MPa})$ demonstrates another pattern: stress pressure mainly triggers defects in the octahedral lattice, which proves the statistical correlation between pressure and the content of aluminum oxide $\left(r_{p}=-0.82>r_{\mathrm{T}}=0.34\right)$ and $\mathrm{MgO}$ $\left(r_{p}=-0.80>r_{\mathrm{T}}=0.34\right)$. The tetrahedral lattice did not reveal defectiveness, which is confirmed by the insignificant statistical correlations between $P$ and $\mathrm{SiO}_{2}$ $\left(r_{p}=0.20<r_{\mathrm{T}}=0.34\right)$.

So, when stress pressure is exerted on kaolin, the structural package of kaolinite develops defects caused by the displacement of $\mathrm{Al}, \mathrm{Fe}, \mathrm{Mg}$, Si. That said, the most significant influence of pressure is seen on the removal of $\mathrm{Al}$ atoms from kaolinite.

From the physical point of view, the atoms are supposed to be removed from the octa- and tetrahedral sheets simultaneously with the weakening of bond "strength" up to its disruption between atoms (ions) in the structural package. For this reason let us consider changes in this "strength" of bonds between atoms using infrared spectroscopy (IR).

Effect of Pressure on Changes in Defectiveness in the Kaolinite Package based on IR Spectroscopy. The defectiveness in the structural package of kaolinite was estimated using the method of infrared spectroscopy. The IR-spectrogram shows the bond between atoms in the structural package as peaks (spikes) that can be characterized through the following indicators: wave number $(v)$ and peak area $(S)$.

From the physical point of view, the peak area $S$ (integral absorption rate) is seen as the oscillation range of each atom in the studied group, for instance, Al-OH. With $S$ tending to zero, the oscillation range of atoms in the studied group reaches such an extent that the bond between them breaks completely. Therefore, the $S$ indicator can be used as a parameter to estimate the "strength" of bonds in atom (ion) groups that make up the kaolinite package, which is in line with previous studies [30, 31].

The wave number characterizes the resonance frequency between atoms in the studied group; in other words, it indicates the intensity of valency or deformation oscillations in the atom groups. The change in the resonance frequency suggests that the valency or deformation oscillations in atom groups change, which implies that the structure of the 


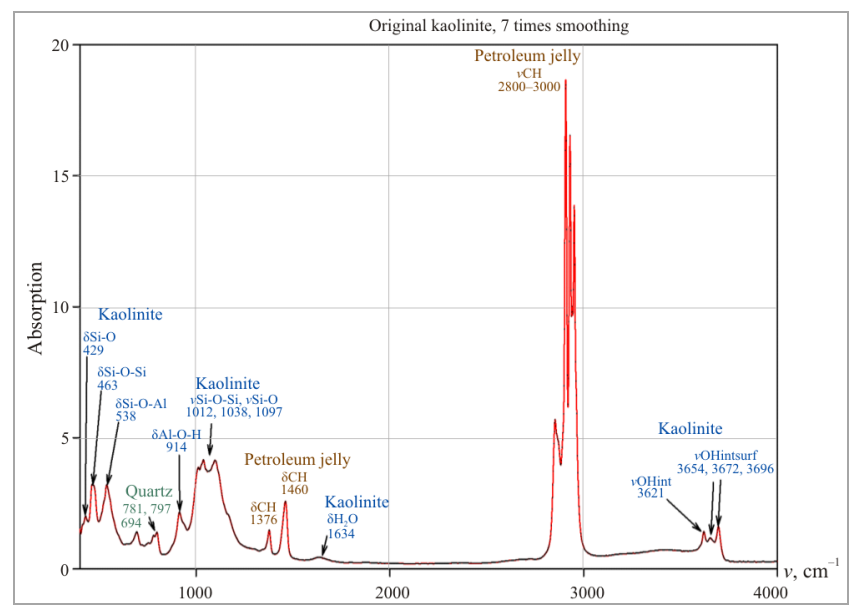

Fig. 2. Infrared spectrum of original kaolinite: $v=400-1200 \mathrm{~cm}^{-1}$ and $v=3600-3720 \mathrm{~cm}^{-1}$

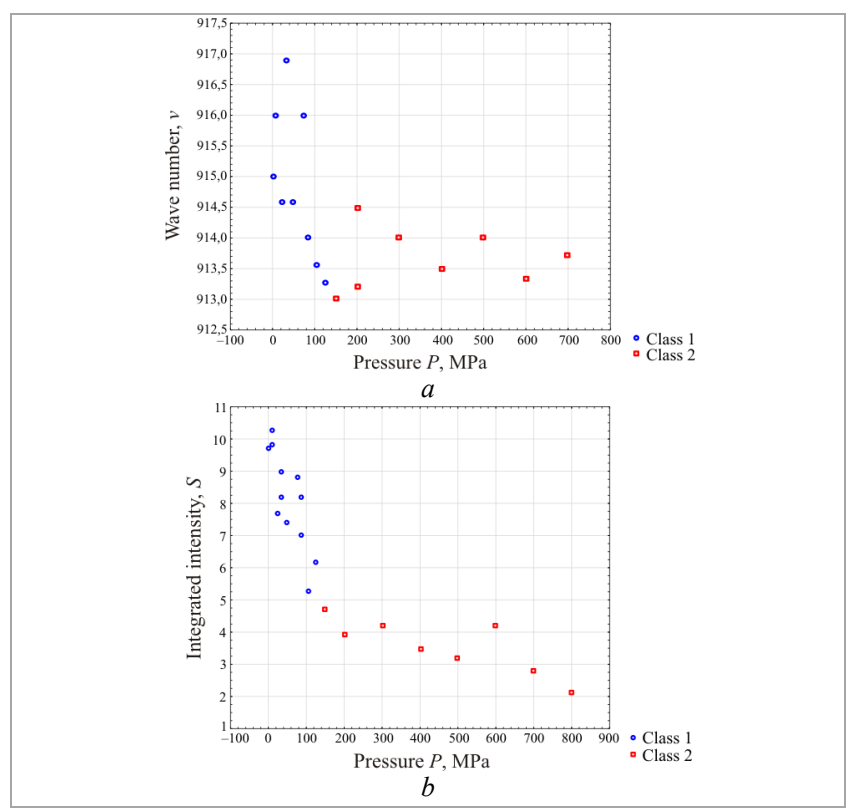

Fig. 3. Change in the bond "strength" between $\delta \mathrm{Al}-\mathrm{OH}-\mathrm{Al}$ under pressure $(P)$ as per parameters: $a$ - wave number $(v)$; $b$ - integral absorption rate $(S)$

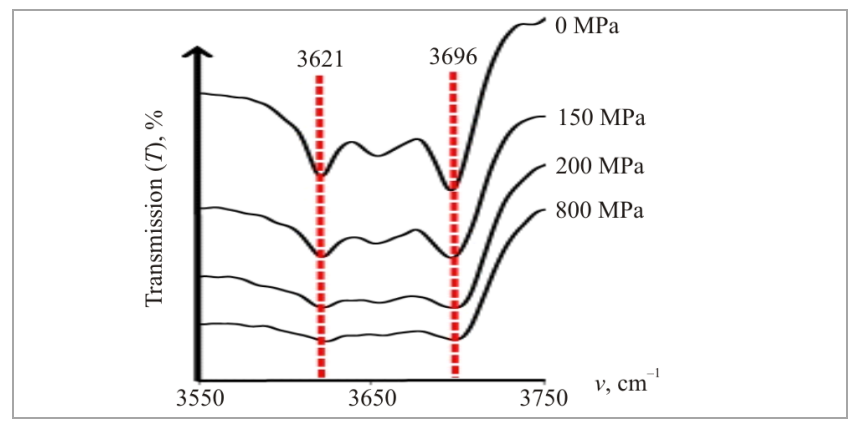

Fig. 4. Infrared spectrum of kaolinite samples under pressure in the range of wave numbers of $3550-3750 \mathrm{~cm}^{-1}$

kaolinite package alters as well. At the same time, the decrease in the wave number is supposed to imply the loss of bond between atoms. Therefore, the $v$ indicator can be used as a parameter that shows changes in the structure of the kaolinite package.

The other parameter that indicates the change in the package structure can be the bands of valency oscillations of hydroxyl groups $(\mathrm{OH})$ in the octahedral sheet. Defectfree (ordered) kaolinite has four well-defined bands of
$\mathrm{OH}$ absorption at wave numbers of $3695 ; 3670 ; 3650$ and $3620 \mathrm{~cm}^{-1}$. Increasing defectiveness of kaolinite causes the bands 3670 and $3650 \mathrm{~cm}^{-1}$ to merge into one inexplicit peak $[22,32]$.

Parameter $K_{3}=I_{3695} / I_{3620}$, i.e. relation of absorption band intensities in the intrasurface hydroxyl groups $\mathrm{wOH}_{\text {i.s. }}$ $\left(I_{3695}\right)$ to the inner hydroxyl groups $\mathfrak{O H}_{\text {in. }}\left(I_{3620}\right)$, also, $K_{4}=I_{3695} / I_{915}$ stands for the relation of the intrasurface hydroxyl groups $\mathrm{DH}_{\mathrm{is.}}\left(I_{3695}\right)$ to $\delta \mathrm{Al}-\mathrm{OH}-\mathrm{Al}\left(I_{915}\right)$ that can be used to estimate defectiveness in the kaolinite structure [33]. These parameters are interpreted in the following manner: the lower their values are, the more defective the structural package of kaolinite is.

Estimation of Structure Defectiveness in the Octahedral Sheet based on $\delta \mathrm{Al}-\mathrm{OH}-\mathrm{Al}$. The structure of the octahedral sheet involves $\mathrm{Al}$ ions that are located in the center of the octahedron, and ions of hydroxyl groups. The results of the experimental study into the "strength" of $\delta \mathrm{Al}-\mathrm{OH}-\mathrm{Al}$ bonds at the wave number of $914 \mathrm{~cm}^{-1}$ in kaolinite affected by stress pressure in the transmission mode are presented in Fig. 3.

Fig. 3 shows that when pressure is increased to $150 \mathrm{MPa}$, the peak area $(S)$ and wave number $(v)$ decrease significantly, whereas at pressures 150-800 MPa the effect of $P$ on the change in $S$ and $v$ is hard to detect. It points to the fact that the decrease in the bond "strength" between $\delta \mathrm{Al}-\mathrm{OH}-\mathrm{Al}$ ions is affected by pressures below $150 \mathrm{MPa}$ to a greater extent than those exceeding $150 \mathrm{MPa}$ (Table 4).

As we see, at pressures $<150 \mathrm{MPa}$ the indicators $S$ and $v$ show reduced strength of bonds between $\mathrm{Al}$ and $\mathrm{OH}$ to the extent of their disruption, which explains the mechanism of how the $\mathrm{Al}$ ions are removed from the octahedral sheet of kaolinite and goes in line with the study findings [34].

Estimation of Defectiveness of the Kaolinite Package Structure based on the Valency Oscillations in Hydroxyl Groups. The results of the experimental study showed that the original sample of kaolinite has three distinct peaks of oscillations in OH-groups: $3696 ; 3654 ; 3620 \mathrm{~cm}^{-1}$ and one less defined peak $-3672 \mathrm{~cm}^{-1}$ (Fig. 4).

Kaolinite exposed to stress pressure of 10 to $400 \mathrm{MPa}$ shows a poorly defined peak of $3672 \mathrm{~cm}^{-1}$ that extends to the arm. At pressures from 450 to $700 \mathrm{MPa}$, the arm of $3672 \mathrm{~cm}^{-1}$ merges with the peak of $3654 \mathrm{~cm}^{-1}$, which is typical of the defective structure of kaolinite. At higher pressures (up to $800 \mathrm{MPa}$ ) there are only two peaks - about 3696 and $3621 \mathrm{~cm}^{-1}$. It suggests the influence of pressure on the increase in defectiveness of the kaolinite structure package. The obtained results do not contradict the findings [31, 35].

Estimation of Kaolinite Defectiveness based on the Intensity of Absorption Bands of Hydroxyl Groups. Figure 5 shows the results of research into changes in intensities of absorption bands of hydroxyl groups $K_{3}=\mathrm{I} 3695 / 3620$ and $K_{4}=$ I3695/915 under pressure. It can be observed that increased pressures tend to lower $K_{3}=\mathrm{I} 3695 / 3620$ from 1.3 to 0.88 , and $K_{4}=13695 / 915$ from 0.8 to 0.6 . The most significant changes take place in the range of pressures from 0 to $150 \mathrm{MPa}$ (Class 1), as opposed to 150 to $800 \mathrm{MPa}$ (Class 2), which is in accordance with the study carried out by V.V Seredin et al. [36].

The identified downward pattern of $I_{3695} / 3620$ and $I_{3695} /{ }_{915}$ at increased pressures suggests that when kaolinite is under pressure the bonds between $\mathrm{Al}$ and $\mathrm{OH}$ ions are disrupted: the ions are removed from the octahedral sheet, which leads to higher defectiveness of the kaolinite package. This finding is fully in line with the results obtained by Fang et al. [15].

The qualitative estimation of the effect of pressure on $K_{3(3695 / 3620)}$ and $K_{4(3695 / 915)}$ was carried out by means of a correlation analysis (Table 5 ). 
Table 4

Effect of pressure on the development of defectiveness of kaoline structural elements

\begin{tabular}{|c|c|c|c|}
\hline \multirow{2}{*}{ Structural element } & \multirow{2}{*}{ Defectiveness indicator } & \multicolumn{2}{|c|}{ Structural element defectiveness } \\
\hline & & $P=0-150 \mathrm{MPa}$ & $P=150-800 \mathrm{MPa}$ \\
\hline Package & Content of $\mathrm{Al}$ ions, $\%$ & Increases & Increases \\
\hline Mineral & Area of coherent scattering, Wc, A & Decreases & Increases \\
\hline Colloid & Zeta-potential, $\mathrm{mV}$ & Decreases & Not defined \\
\hline Aggregate & Adhesive power, $F_{\text {п }}$ & Increases & Increases \\
\hline
\end{tabular}

Table 5

Correlation matrix

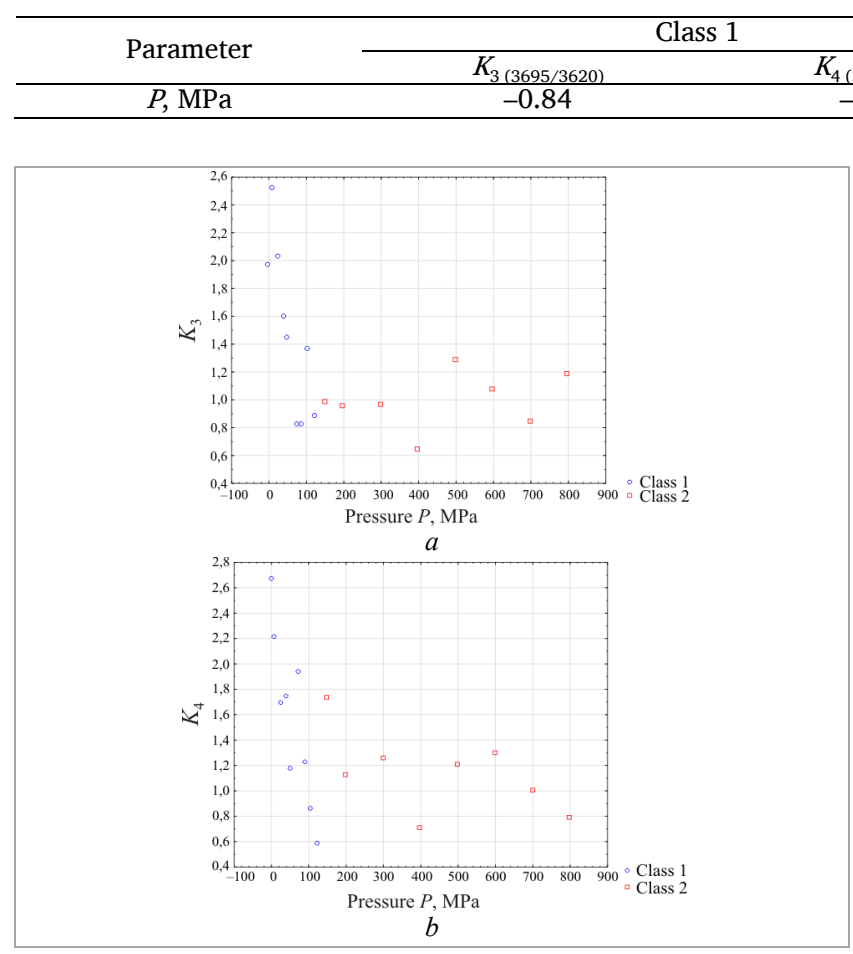

Fig. 5. Change in the intensity of absorption bands: $a-K_{3(3695 / 3620)} ; b-K_{4(3695 / 914)}$ under pressure $(P)$

It can be seen that based on the obtained data pressure and $K_{3(3695 / 3620)}, K_{4(3695 / 915)}$ are statistically related. It indicates that pressure has a significant effect on the formation of defects at the level of structural packages of kaolinite.

Therefore, when kaolin clay is pressurized at $800 \mathrm{MPa}$ the package suffers the removal of $\mathrm{Al}$ and $\mathrm{Si}$ ions from the octahedral and tetrahedral sheets to form local "hole"like defects accounting for $2-3 \%$ in volume. The detected displacement (deformation) of ions in the kaolinite package is suggested by the decrease in integral transmission intensity $S$ at increased pressures. Effect of Pressure on Structural Changes in Kaolinite Mineral.

The influence of pressure on changes in the structure of kaolinite was studied using IR spectroscopy and diffraction analysis. The change in the structure of crystallite (mineral) implies compaction, slips, and rotation of kaolinite packages in relation to one another. These changes can be interpreted as defectiveness of kaolinite mineral.

Estimation of mineral defectiveness using $\delta \mathrm{H}-\mathrm{O}-\mathrm{H}$. It is well known that kaolinite packages are bound to one another though a hydrogen bond, so that ions of the $\mathrm{OH}$ surface hydroxyl groups in the octahedral sheet of one package are bound to atoms of oxygen $\mathrm{O}$ in the tetrahedral sheet of another package. Therefore, when the bond between $\mathrm{O}-\mathrm{H}-\mathrm{O}$ ions is disrupted, it quite likely indicates that we face an event of kaolinite packages rolling, sliding, and rotating in relation to one another.

The results of the experimental study are given in Fig. 6 .

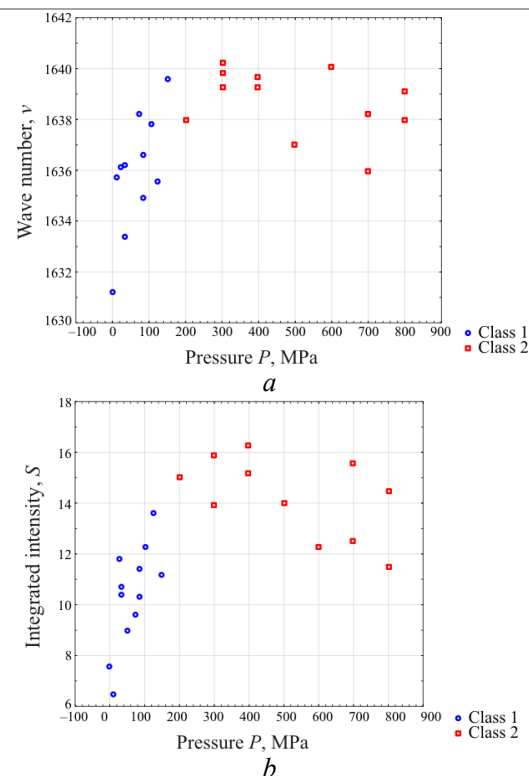

Fig. 6. Changes in the "strength" of bonds between $\delta \mathrm{H}-\mathrm{O}-\mathrm{H}$ ions under pressure $(P)$ as per parameters: $a$ - wave number $(v) ; b$ - integral absorption rate $(S)$

As is seen from Fig. 6, the pressure of up to $150 \mathrm{MPa}$ increases the integral absorption rate $S$, whereas when the pressure goes up to $800 \mathrm{MPa} S$, on the contrary, drops. This kind of pattern points towards the fact that when kaolinite is affected by pressures up to $150 \mathrm{MPa}$ its structure is aligned so its defectiveness goes down. It can be explained the following way: at pressures up to $150 \mathrm{MPa}$ the kaolinite package loses about $2 \%$ of Al ions as a result of the disruption in the bond between $\mathrm{Al}$ and $\mathrm{OH}$. The hydroxyl groups, while dissociating, deliver hydrogen ions to the inter-package space, which strengthens the bond between the kaolinite packages.

As the pressure grows from 150 to $800 \mathrm{MPa}$ the bonds between $\mathrm{H}-\mathrm{O}-\mathrm{H}$ ions are disrupted, which leads to higher defectiveness of the kaolinite mineral as a result of the packages being displaced in relation to one another. The resulting data go in line with the studies [37].

Estimation of Mineral Defectiveness based on the Data Drawn from Diffraction Analysis. The X-diffraction patterns (Fig. 7) show that the most sensitive indicators that characterize changes in the mineral structure under pressure are: peak half-width $\left(h_{1}\right)$, integral intensity - peak area $\left(s_{1}\right)$, interplane spacing $\left(d_{1}\right)$ and the angle $2 \theta\left(a_{1}\right)$ of maximum diffraction incidence [38].

To enhance the reliability and accuracy of estimation of the kaolinite mineral structure defectiveness we used the complex indicator of the area of coherent scattering (ACS). 


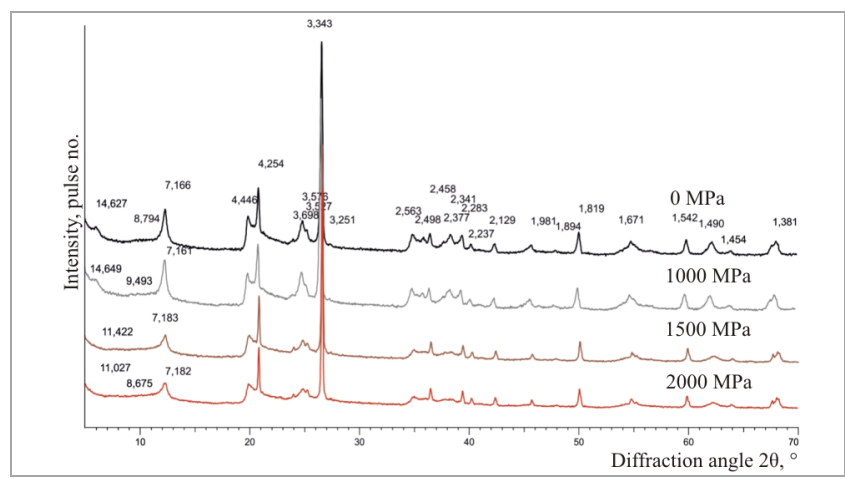

Fig. 7. X-ray diffraction patterns in kaolin clay samples: original and pressurized

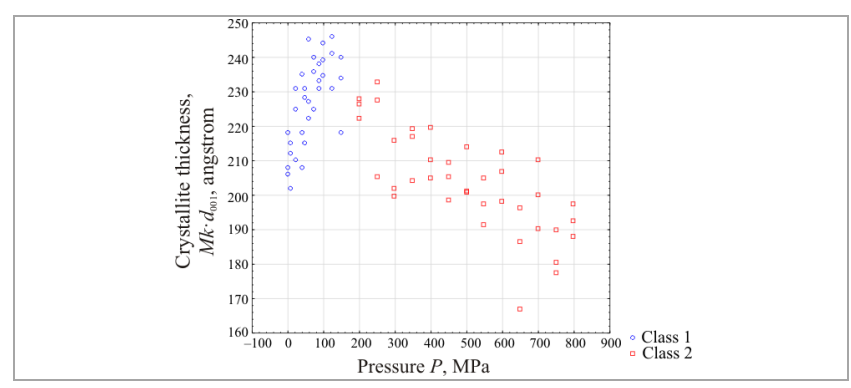

Fig. 8. Influence of pressure on changes in the width $(W c)$ of crystallite

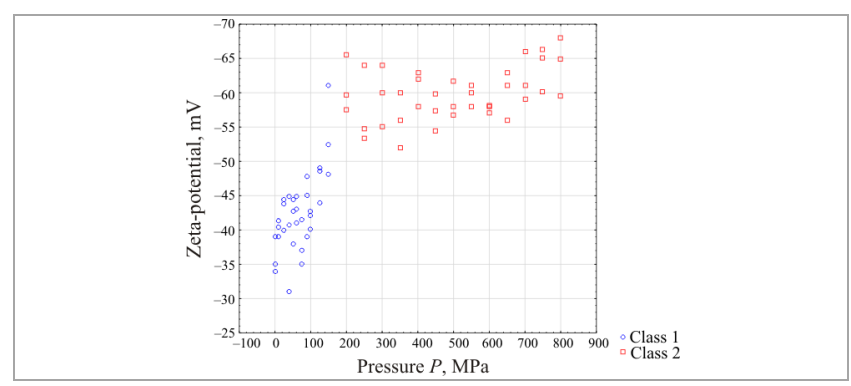

Fig. 9. Influence of pressure on changes in zeta-potential $(\zeta)$ of the colloid

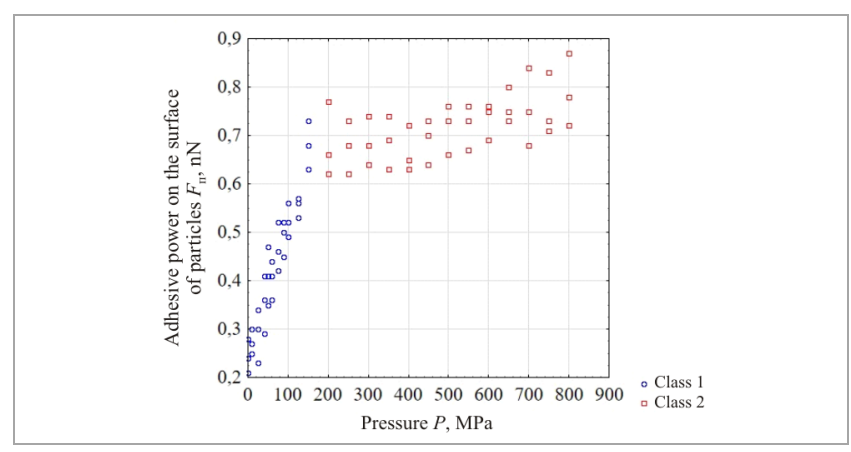

Fig. 10. Changes in adhesion strength $\left(F_{\mathrm{s}}\right)$

on the surface of kaolin aggregates under pressure $(P)$

The area of coherent scattering implies crystal with the defect-free structure. This indicator correlates with the energy activity of particles. Small values of ACS indicate that the microblocks are small in size and have high capacity for cation exchange [38], which points to a high energy potential of the particle. Besides, the study conducted by V.G. Shlykov [39] notes that small values of ACS generally suggest that there are water molecules between the microblocks that facilitate random displacement of packages in relation to one another, which leads to higher energy activity on the surface of particles. Namely, with ACS expressed by means of the indicator $W c>40$ (number of packages in defect-free crystallites), the cation exchange capacity (CEC) is 2-5 mg-eqv/100 g, at $W c=40-25$ the capacity grows to $\mathrm{CEC}=6-12 \mathrm{mg}$-eqv $/ 100 \mathrm{~g}$, and at $W c<25$ the capacity has low values - CEC > $12 \mathrm{mg}$-eqv/100 $\mathrm{g}$ [38].

Therefore, the parameter Wc (area of coherent scattering) can be used as a complex indicator as it combines the peak half-width, angle of maximum diffraction incidence and X-ray radiation wavelength. $W c$ is calculated using the Scherrer equation based on the width of the first basal peak [12]:

$$
W c=\lambda / \cos \Theta \cdot h_{1},
$$

where $\lambda=1,54060 \AA$ - the length of the X-ray radiation wave; $\Theta$ - the angle of diffraction; $h_{1}$ - basal peak half-width.

Fig. 8 shows the correlation field between the parameters $W c$ and $P$ in kaolin clay: as pressure rises to 125-150 MPa, it thickens the crystallite $(W c)$; further increase of pressure to $800 \mathrm{MPa}$ lowers the value of $W c$.

In other words, whenever pressure rises to $150 \mathrm{MPa}$, it aligns the kaolinite structure, which brings the structure defectiveness down by $20 \%$, whereas at pressures climbing up to $800 \mathrm{MPa}$ the crystallite defectiveness increases by 15-20\% compared with the original level.

Therefore, when kaolin clay is pressurized at up to $150 \mathrm{MPa}$, the mineral (crystallite) made up of 20-40 packages shows a better aligned structure, which suggests lower defectiveness. At pressures $>150 \mathrm{MPa}$, there is higher crystallite defectiveness due to the displacement of packages in relation to one another (see Table 4).

\section{Influence of Pressure on Changes in Kaolin Structure at the Colloid (Particle) Level}

Clay particles (colloids) are known to form a double electric layer on their surface that is largely defined by the energy potential of the particle surface. One of the indicators of the energy potential is zeta-potential [40] that is formed on the slip boundary between the absorption and diffusion layers. Zeta-potential is characterized by the charge (defectiveness) of the particle and thus can be used as an indicator of the particle defectiveness.

Fig. 9 presents the results of the experimental studies on the influence of pressure on the zeta-potential of kaolin particles: with the pressure increase to $150 \mathrm{MPa}$, the structure defectiveness goes down due to the increase in the colloid density $\left(r_{p}=0.67\right)$. In the range of $150-800 \mathrm{MPa}$, it is quite hard to identify the effect pressure has $\left(r_{p}=0.37\right)$ on the defectiveness formation (see Table 4).

\section{Influence of Pressure on Changes \\ in Kaolin Structure at the Aggregate Level}

The change in the aggregate structure takes place due to the fragmentation of large structural elements and processes of compression and compaction of kaolin particles under externally exerted pressure. Such changes manifest as morphological alterations on the aggregate surface that can be expressed using the indicator of aggregate surface roughness. The aggregate surface roughness is manifested through the surface energy, therefore the aggregate structure defectiveness can be estimated using the energy indicator: adhesive strength of the aggregate surface $\left(F_{s}\right)$. Adhesive strengths were measured using the atomic-force microscope (AFM) NT-MDT NTEGRA Prima (Russia). The resulting AFMimages were processed and quantitatively analyzed on Nova 1.1.1 Revision 14785 NT-MDT Tech.

The results of the experimental research into forces of adhesive interaction $\left(F_{\mathrm{s}}\right)$ between the cantilever and the aggregate surface under pressure are presented in Fig. 10. 
As the data in Fig. 10 suggest, there is a rise in adhesion strength across the entire range of pressures. At the same time, in the range of $0-150 \mathrm{MPa}$, the influence of pressure on adhesive strength is higher that in the pressure range of $150-800 \mathrm{MPa}$.

The results of the correlation analysis show that the calculated values of correlation coefficients $\left(r_{p}\right)$ exceed the critical value $\left(r_{\mathrm{T}}=0.27\right)$ found at $n=54, \alpha=0.05$. Therefore, it can be stated that pressure affects the formation of adhesive forces on the aggregate surface. However, in Class 1, there is a stronger statistical correlation between the pressure and force of adhesive interaction than in Class 2. It is indicated by higher correlation coefficients: namely, for an aggregate in Class 1, the calculated correlation coefficient between $P$ and $F_{s}$ stands at 0.95, whereas in Class 2 it is $r_{p}=0.58$.

The revealed changes in adhesive forces depending on exerted pressure are due to the structural alterations (defectiveness) of the aggregate, which goes in line with the findings of E. Galan [41].

Therefore, technology-induced treatment of clays has conflicting effects on their composition, structure, and properties [42-46].

\section{Conclusion}

1. High pressures have conflicting effects on the formation of defectiveness in structural elements of kaolin, specifically its package, mineral, colloid, and aggregate.
2. The kaolinite mineral package shows higher defectiveness at higher pressures. Defects are formed as a result $\mathrm{Al}, \mathrm{Fe}, \mathrm{Mg}, \mathrm{Si}$ ions being displaced from the octahedral and tetrahedral sheets. $\mathrm{Al}$ ions are most susceptible to pressure. The removal of ions triggers deformations in the package and formation of "hole"-like energy centers. The pressure within 0-150 MPa has a more significant effect on formation of defectiveness $\left(r_{p}=0.86\right)$ than that within the range of $150-800 \mathrm{MPa}\left(r_{p}=0.82\right)$.

3 . The kaolinite mineral pressurized up to $150 \mathrm{MPa}$ shows less defectiveness as a result of its structure alignment $\left(r_{p}=0.67\right)$. At pressures over $150 \mathrm{MPa}$, the kaolinite mineral shows higher defectiveness $\left(r_{p}=-0.72\right)$ as the hydrogen bonds between the packages get disrupted, which forces the structural packages to slip and rotate in relation to one another.

4. The colloid (particle) at pressures going up to $150 \mathrm{MPa}$ shows lower defectiveness due to higher density of the colloid $\left(r_{p}=0.67\right)$. The influence of pressure on formation of defectiveness in the range of $150-800 \mathrm{MPa}$ $\left(r_{p}=0.37\right)$ proved to be hard to reveal.

5. The aggregate under pressure up to $150 \mathrm{MPa}$ shows higher defectiveness as a result of particle fragmentation, as well as slips and displacements of particles in relation to one another $\left(r_{p}=0.95\right)$. The influence of pressure on formation of defectiveness in the range of $150-800 \mathrm{MPa}$ proved to be hard to reveal $\left(r_{p}=0.58\right)$; however, as the pressure increases, it leads to higher defectiveness overall.

Refernces

1. Osipov V.I., Sokolov V.N., Rumiantseva N.A. Mikrostruktura glinistykh porod [Clay microstructure]. Moscow: Nedra, 1989,211 p.

2. Osipov V.I., Sokolov V.N. Gliny i ikh svoistva [Clays and their properties]. Moscow: Geos, 2013, 576 p.

3. Kara-Sal B.K., Sapelkina T.V. Povyshenie adsorbtsionnykh svoistv glinistykh porod Tuvy v zavisimosti ot metodov aktivatsii [Increasing the adsorption properties of Tuva clay rocks depending on activation methods]. Aktual'nye problemy sovremennoi nauki, 2012, no. 5, p. 158-162.

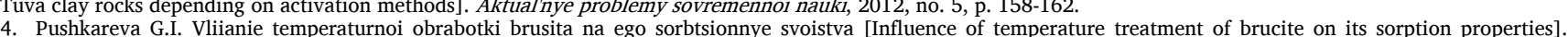
4. Pushkareva G.I. Vliianie temperaturnoi obrabotki brusita na ego sorbtsionnye svoist

5. Range K.J., Range A., Weiss A. Fire-clay type kaolinite or fire-clay mineral. Experimental classification of kaolinite-halloysite minerals. Proc. Int. Clay Conf. Tokyo, 1969, pp. 3-13.

6. Sapronova Zh.A., Lesovik V.S., Gomes M.Zh., Shaikhieva K.I. Sorbtsi-onnye svoistva UF-aktivirovannykh glin Angol'skikh mestorozhdenii [Sorption properties of UVactivated clays of Angola deposits]. Vestnik Kazakhskogo natsional"nogo tekhnicheskogo universiteta, 2015, vol. 18, no. 1, pp. 91-93.

7. Nichiporenko S.P., Kruglitskii N.N., Panasevich A.A., Khil'ko V.V. Fiziko-khimicheskaia mekhanika dispersnykh mineralov [Physicochemical mechanics of dispersed minerals]. Kiev: Naukova dumka, 1974, 243 p.

8. Suraj G., Iyer C.S.P., Rugmini S., Lalithambika M. The effect of micronization on kaolinites and their sorption behavior. Applied Clay Science, 1997, vol. 12, no. 1-2, pp. 111-130. DOI: 10.1016/S0169-1317(96)00044-0

9. Kossovskaia A.G., Shutov V.D., Drits V.A. Glinistye mineraly - in-dikatory glubinnogo izmeneniia terrigennykh porod [Clay minerals - indicators of deep changes in terrigenous rocks]. Geokhimiia, mineralogiia i petrografiia osadochnykh obrazovanii. Ed. akademik D.I. Shcherbakov. Moscow: Izdatel'stvo Akademii nauk SSSR, 1963, pp. $120-131$.

rocks]. Geokhimiia, mineralogiia i petrografiia osadochnykh obrazovanii. Ed. akademik D.I. Shcherbakov. Moscow: Izdatel'stvo Akademii nauk SSSR, 1963, pp. 120-131. 3 . 10. Goilo E.A., Kotov N.V., Frank-Kamenetskii V.A. Eksperimental'noe issledovanie vliianiia davleniia i temperatury na kristallicheskie struktury kaolinita, illita i
montmorillonita [Experimental study of the effect of pressure and temperature on the crystal structures of kaolinite, illite and montmorillonite]. Fizicheskie metody

11. Frank-Kamenetskii V.A., Kotov N.V., Goilo E.A. Izmenenie struktury glinistykh mineralov v razlichnykh temodinamicheskikh usloviiakh [Changes in the structure of clay minerals under different temodynamic conditions]. Rentgenografiia mineral'nogo syr'ia. Moscow: Nedra, 1970, no. 7, pp. 166-174.

12. Frank-Kamenetskii V.A. Rentgenografiia osnovnykh tipov porodoobrazuiushchikh mineralov (sloistye i karkasnye silikaty) [Radiography of the main types of rockforming minerals (layered and frame silicates)]. Leningrad: Nedra, 1983, $359 \mathrm{p}$.

13. La Iglesia A. Pressure induced disorder in kaolinite. Clay Minerals, 1993, vol. 28, no. 2, pp. 311-319. DOI: 10.1180/claymin.1993.028.2.11

14. Galan E., Aparicio P., Gonzalez Â., La Iglesia A. The effect of pressure on order/disorder in kaolinite under wet and dry conditions. Clays and Clay Minerals, 2006, vol. 54, no. 2, pp. 230-239. DOI: 10.1346/CCMN.2006.0540208

15. Fang et al. Pressure dependence of the electronic structure in kaolinite: a first-principles study. Modern Physics Letters B, 2017, vol. 31, no. 12, pp. 1-10.

DOI: $10.1142 /$ S0217984917501949

16. Welch et al. Insights into the high-pressure behavior of kaolinite from infrared spectroscopy and quantum-mechanical calculations. Physics and Chemistry of Minerals, 2012, vol. 39(2), pp. 143-151. DOI: $10.1007 /$ s00269-011-0469-5

17. Boldyrev V.V. Mekhanokhimiia i mekhanicheskaia aktivatsiia tverdykh veshchestv [Mechanochemistry and mechanical activation of solids]. Uspekhi khimii, 2006, vol. 75, no. 3, pp. 203-216. DOI: 10.1070/RC2006v075n03ABEH001205

18. Ehrenberg S.N., Aagaard P., Wilson M.J., Fraser A.R., Duthie D.M.L. Depth-dependent transformation of kaolinite to dickite in sandstones of the Norwegian continental shelf. Clay Minerals, 1993, vol. 28, no. 3, pp. 325-352. DOI: 10.1180/claymin.1993.028.3.01

19. Kossovskaya A.G., Shutov V.D. Facies of regional epi- and metagenesis // International Geology Review, 1965, vol. 7, no. 7, pp. 1157-1167. DOI: 10.1080/00206816509474768 20. Seredin V.V., Rastegaev A.V., Medvedeva N.A., Parshina T.Iu. Vliianie davleniia na ploshchad' aktivnoi poverkhnosti chastits glinistykh gruntov [Influence of pressure on the active surface area of clay soil particles]. Inzhenernaia geologiia, 2017, no. 3, pp. 18-27.

21. Pushcharovskii D.Iu. Rentgenografiia mineralov [Radiography of minerals]. Moscow: Geoinformmark, 2000, 288 p.

22. Tarasevich B.N. Osnovy IK spektroskopii s preobrazovaniem Fur'e. Podgotovka prob v IK-spektroskopii [Fundamentals of Fourier Transform IR Spectroscopy. Sample preparation in IR spectroscopy]. Moscow: Moskovskii gosudarstvennyi universitet imeni M.V. Lomonosova, 2012, $22 \mathrm{p}$.

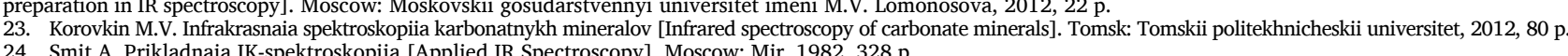

25. Kubekova Sh.N., Tanau A. Ispol'zovanie metoda IK-spektroskopii dlia opredeleniia molekuliarnogo sostava neorganicheskikh veshchestv: metod. ukazaniia $\mathrm{k}$ laboratornym zaniatiiam [Using the method of IR spectroscopy to determine the molecular composition of inorganic substances: method. instructions for laboratory exercises]. Almaty: Kazakhskii natsional'nyi issledovatel'skii tekhnicheskii universitet imeni K.I. Satpaeva, 2014, 17 p.

26. Seredin V.V., Parshina T.Yu., Rastegaev A.V., Galkin V.I., Isaeva G.A. Changes of energy potential on clay particle surfaces at high pressures. Applied Clay Science, 2018, vol. 155, pp. 8-14. DOI: 10.1016/j.clay.2017.12.042

27. Kotel'nikov D.D., Koniukhov A.I. Glinistye mineraly osadochnykh porod [Clay minerals of sedimentary rocks]. Moscow: Nedra, $1986,247 \mathrm{p}$.

28. Seredin V.V., Medvedeva N.A., Aniukhina A.V., Andrianov A.V. Za-konomernosti izmeneniia soderzhaniia sviazannoi vody v kaolinovoi gline pri ee szhatii vysokimi davleniiami [Regularities of the bound water content variation in kaolin clay under high pressure]. Vestnik Permskogo universiteta. Geologiia, 2018, vol. 17, no. 4, pp. 359-369. DOI: 10.17072/psu.geol.17.4.359

29. Medvedeva N.A., Siteva O.S., Seredin V.V. Sorbtsionnaia sposobnost' glin, podverzhennykh szhatiiu [Sorption ability of clays exposed to compression]. Vestnik Permskogo 29. Medvedeva N.A., Siteva O.S., Seredin V.V. Sorbtsionnaia sposobnost' glin, podverzhennykh szhatiiu [Sorption ability of clays exposed to compression]. Vestnik Perm
natsional'nogo issledovatel'skogo politekhnicheskogo universiteta. Geologiia. Neftegazovoe i gornoe delo, 2018, vol. 18, no. 2, pp. 118-128. DOI: 10.15593/2224-9923/2018.4.2 natsional nogo issledovatelskogo politekhnicheskogo universiteta. Geologiia. Neftegazovoe i gornoe delo, 2018, vol. 18, no. 2, pp. 118-128. DOI: 10.15593/2224-9923/2018

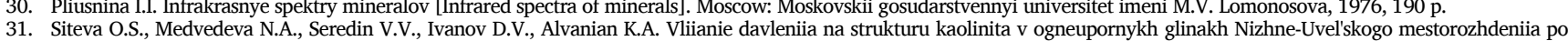
dannym IK-spektroskopii [Influence of pressure on the structure of kaolinite in fire-clays of the Nizhne-Uvelskogo deposit by IR spectroscopy]. Izvestiia Tomskogo politekhnicheskogo universiteta. Inzhiniring georesursov, 2020, vol. 331, no. 6, pp. 208-217. DOI: 10.18799/24131830/2020/6/2690 
32. Uorrel U. Gliny i keramicheskoe syr'e [Clays and ceramic raw materials]. Moscow: Mir, 1978, $241 \mathrm{p}$

33. Lazarev A.N., Mirgorodskii A.P., Ignat'ev I.S. Kolebatel'nye spektry slozhnykh okislov: silikaty i ikh analogi [Vibrational spectra of complex oxides: silicates and their analogues]. Leningrad: Nauka, Leningradskoe otdelenie, 1975, $296 \mathrm{p}$

34. Gates W.P., Kloprogge J.T., Madejova J., Bergaya F., Gates W.P., Petit S. Infrared and Raman Spectroscopies of Clay Minerals. Elsevier, 2017, vol. 8, 620 p.

35. Plastinina M.A. et al. Nekotorye osobennosti proiavleniia nesovershenstva kaolinitov na ikh infrakrasnykh spektrakh pogloshcheniia [Some features of the manifestation of imperfection of kaolinite in their infrared absorption spectra]. Mineralogicheskii sbornik, 1979, no. 33, iss. 1, pp. 27-32.

36. Seredin V.V., Rastegayev A.V., Panova E.G., Medvedeva N.A. Changes in physical properties of clay under compression. International Journal of Engineering and Applied Sciences, 2017, vol. 4, no. 3, 22 p.

37. Zhu Xiaoyan, Zhu Zhichao, Lei Xinrong, Yan Chunjie Defects in structure as the sources of the surface charges of kaolinite. Applied Clay Science, 2016, vol. 124-125, pp. 127-136. DOI: $10.1016 /$ j.clay.2016.01.033

pp. 127-136. DOI: 10.1016/j.clay.2016.01.033 Geos, 2006, $176 \mathrm{p}$.

39. Shlykov V.G. Ispol'zovanie strukturnykh kharakteristik glinistykh mineralov dlia otsenki fiziko-khimicheskikh svoistv dispersnykh gruntov [Using the structural characteristics of clay minerals to assess the physicochemical properties of dispersed soils]. Geoekologiia, 2000, no. 1, pp. 43-52.

40. Seredin V.V., Krasil'nikov P.A., Medvedeva N.A. Izmenenie elektrokineticheskogo potentsiala glinistykh kolloidov v vodnoi i uglevodorodnoi sredakh [Variation of electrokinetic potential of clayey colloids in aquatic and hydrocarbon media]. Geoekologiia. Inzhenernaia geologiia, gidrogeologiia, geokriologiia, 2017, no. 1, pp. 66-74.

41. Seredin V.V., Medvedeva N.A., Mal'gina Iu.O., Peshkova T.A. Izuchenie svoistv glinistykh porod pri razrabotke solianykh mestorozhdenii [Study of the properties of clay rocks in the development of salt deposits]. Sovremennye tekhnologii v stroitel'stve. Teoriia i praktika, 2016, vol. 2, pp. 451-454.

42. Tarasevich Iu.I., Ovcharenko F.D. Adsorbtsiia na glinistykh mineralakh [Adsorption on clay minerals]. Kiev: Naukova dumka, 1975,351 p.

43. Vaculíkova L., Plevová E., Vallová S., Koutník I. Characterization and differentiation of kaolinites from selected Czech deposits using infrared spectroscopy and differential thermal analysis. Acta Geodynamica et Geomaterialia, 2011, vol. 8, no. 1, pp. 59-67.

44. Laita E., Bauluz B. Mineral and textural transformations in aluminium-rich clays during ceramic firing. Applied Clay Science, 2018 , vol. 152, p. 284-294. DOI: $10.1016 /$ j.clay.2017.11.025

45. Vakalova T.V., Reshetova A.A., Revva I.B., Rusinov P.G., Balamygin D.I. Effect of thermochemical activation of clay raw materials on phase formation, microstructure and properties of aluminosilicate proppants. Applied Clay Science, 2019, vol. 183, 105335 p. DOI: 10.1016/j.clay.2019.105335

46. Sruthi P.L., Reddy P.H. Swelling and mineralogical characteristics of alkali-transformed kaolinitic clays. Applied clay science, 2019, vol. 183, 105353 p. 46. Sruthi P.L., Reddy P.H. Swelli: $10.1016 /$ j.clay.2019.105353
DOI:

\section{Список литературы}

1. Осипов В.И., Соколов В.Н., Румянцева Н.А. Микроструктура глинистых пород. - М.: Недра, 1989. - 211 с.

2. Осипов В.И., Соколов В.Н. Глины и их свойства. - М.: Геос, 2013. - 576 с.

3. Кара-Сал Б.К., Сапелкина Т.В. Повышение адсорбционных свойств глинистых пород Тувы в зависимости от методов активации // Актуальные проблемы современной науки. - 2012. - № 5. - С. 158-162.

4. Пушкарева Г.И. Влияние температурной обработки брусита на его сорбционные свойства // Физико-технические проблемы разработки полезных ископаемых - 2000. - № 6. - С. $90-93$.

5. Range K.J., Range A., Weiss A. Fire-clay type kaolinite or fire-clay mineral. Experimental classification of kaolinite-halloysite minerals // Proc. Int. Clay Conf. - Tokyo, 1969. - P. 3-13.

6. Сорбционные свойства УФ-активированных глин Ангольских месторождений / Ж.А. Сапронова, В.С. Лесовик, М.Ж. Гомес, К.И. Шайхиева // Вестник КазНИТУ. - 2015. - Т. 18, № 1. - С. 91-93.

7. Физико-химическая механика дисперсных минералов / С.П. Ничипоренко, Н.Н. Круглицкий, А.А. Панасевич, В.В. Хилько. - Киев: Наукова думка, 1974. - 243 с.
8. The effect of micronization on kaolinites and their sorption behavior / G. Suraj, C.S.P. Iyer, S. Rugmini, M. Lalithambika // Applied Clay Science. - 1997. - Vol. 12,

№ 1-2. - P. 111-130. DOI: 10.1016/S0169-1317(96)00044-0

9. Коссовская А.Г., Шутов В.Д., Дриц В.А. Глинистые минералы - индикаторы глубинного изменения терригенных пород // Геохимия, минералогия и 9. Коссовская А.Г., Шутов В.Д., Дриц В.А. Глинистые минералы - индикаторы глубинного изменения терриге и. й.

петрография осадочных образований / под ред. акад. Д.И. Щербакова. - М.: Изд-во АН СССР, 1963. - С. $120-131$. каолинита, иллита и монтмориллонита // Физические методы исследования осадочных пород. - М.: Наука, 1966. - С. 123-129.

11. Франк-Каменецкий В.А., Котов Н.В., Гойло Э.А. Изменение структуры глинистых минералов в различных темодинамических условиях // Рентгенография минерального сырья. - М.: Недра, 1970. - № 7. - С. 166-174.

12. Франк-Каменецкий В.А. Рентгенография основных типов породообразующих минералов (слоистые и каркасные силикаты). - Л.: Недра, 1983. - 359 с.

13. La Iglesia A. Pressure induced disorder in kaolinite // Clay Minerals. - 1993. - Vol. 28, № 2. - P. 311-319. DOI: 10.1180/claymin.1993.028.2.11

14. The effect of pressure on order/disorder in kaolinite under wet and dry conditions / E. Galan, P. Aparicio, Â. Gonzalez, A. La Iglesia // Clays and Clay Minerals. 2006. - Vol. 54, №. 2. - P. 230-239. DOI: 10.1346/CCMN.2006.0540208

15. Pressure dependence of the electronic structure in kaolinite: a first-principles study / Fang [et al.] // Modem Physics Letters B. - 2017. - Vol. 31, № 12 -P. 1-10. DOI: 10.1142/S0217984917501949

16. Insights into the high-pressure behavior of kaolinite from infrared spectroscopy and quantum-mechanical calculations / Welch [et al.] // Physics and Chemistry of Minerals. - 2012. - Vol. 39 (2). - P. 143-151. DOI: 10.1007/s00269-011-0469-5

17. Болдырев В.В. Механохимия и механическая активащия твердых веществ // Успехи химии. - 2006. - T. 75, № 3. - C. 203-216. DOI: 10.1070/RC2006v075n03ABEH001205
18. Depth-dependent transformation of kaolinite to dickite in sandstones of the Norwegian continental shelf / S.N. Ehrenberg, P. Aagaard, M.J. Wilson, A.R. Fraser, D.M.L. Duthie // Clay Minerals. - 1993. - Vol. 28, № 3. - P. 325-352. DOI: 10.1180/claymin.1993.028.3.01

19. Kossovskaya A.G., Shutov V.D. Facies of regional epi- and metagenesis // International Geology Review. - 1965. - Vol. 7, № 7. - P. 1157-1167. DOI: 10.1080/00206816509474768

20. Влияние давления на площадь активной поверхности частиц глинистых грунтов / В.В. Середин, А.В. Растегаев, Н.А. Медведева, Т.Ю. Паршина // Инженерная геология. - 2017. - № 3. - С. 18-27.

21. Пущаровский Д.Ю. Рентгенография минералов. - М.: Геоинформмарк, 2000. - 288 с

22. Тарасевич Б.Н. Основы ИК спектроскопии с преобразованием Фурье. Подготовка проб в ИК-спектроскопии: учеб. пособие. - М.: МгУ, 2012. - 22 с.

23. Коровкин М.В. Инфракрасная спектроскопия карбонатных минералов: учеб. пособие. - Томск: Изд-во Томского политехн. ун-та, $2012 .-80$ с.

24. Смит А. Прикладная ИК-спектроскопия: пер. с англ. - М.: Мир, 1982. - 328 с.

25. Кубекова Ш.Н., Танау А. Использование метода ИК-спектроскопии для определения молекулярного состава неорганических веществ: метод. указания к лабораторным занятиям. - Алматы: КазНТУ имени К.И. Сатпаева, 2014. - 17 с.

26. Changes of energy potential on clay particle surfaces at high pressures / V.V. Seredin, T.Yu. Parshina, A.V. Rastegaev, V.I. Galkin, G.A. Isaeva // Applied Clay Science. - 2018. - Vol. 155. - P. 8-14. DOI: 10.1016/j.clay.2017.12.042

27. Котельников Д.Д., Конюхов А.И. Глинистые минералы осадочных пород. - М.: Недра, 1986. - 247 с.

28. Закономерности изменения содержания связанной воды в каолиновой глине при ее сжатии высокими давлениями / В.В. Середин, Н.А. Медведева, А.В. Анюхина, A.В. Андрианов // Вестник Пермского университета. Геология. - 2018. - T. 17, № 4. - С. 359-369. DOI: 10.17072/psu.geol.17.4.359

А.В. Андрианов // Вестник Пермского университета. Геология. - 2018. - Т. 17, № 4. - С. 359-369. DOI: 10.17072/psu.geol.17.4.359
29. Медведева Н.А., Ситева О.С., Середин В.В. Сорбционная способность глин, подверженных сжатию // Вестник Пермского национального исследовательского 29. Медведева Н.А., Ситева О.С., Середин В.В. Сорбционная способность глин, подверженных сжатию // Вестник Пермского на ния

политехнического университета. Геология. Нефтегазовое и горное дело. - 2018. - Т. 18, № 2. - С. 118-128. D

31. Влияние давления на структуру каолинита в огнеупорных глинах Нижне-Увельского месторождения по данным ИК-спектроскопии / О.С. Ситева, Н.А. Медведева, В.В. Середин, Д.В. Иванов, К.А. Алванян // Известия Томского политехнического университета. Инжиниринг георесурсов. - 2020. - Т. 331, № 6. - С. 208-217. DOI: $10.18799 / 24131830 / 2020 / 6 / 2690$

32. Уоррел У. Глины и керамическое сырье: пер. с англ. - М.: Мир, 1978. - 241 с.

33. Лазарев А.Н., Миргородский А.П., Игнатьев И.С. Колебательные спектры сложных окислов: силикаты и их аналоги / АН СССР. Ин-т химии силикатов им. И. В. Гребенщикова. - Л.: Наука, Ленингр. отд-ние, 1975. - 296 с.

34. Infrared and Raman Spectroscopies of Clay Minerals / W.P. Gates, J.T. Kloprogge, J. Madejova, F. Bergaya, W.P. Gates, S. Petit. - 2017. - Vol. 8.

35. Некоторые особенности проявления несовершенства каолинитов на их инфракрасных спектрах поглощения / М.А. Пластинина [и др.] // Минералогический сборник. - 1979. - № 33, вып. 1. - С. 27-32.

36. Changes in physical properties of clay under compression / V.V. Seredin, A.V. Rastegayev, E.G. Panova, N.A. Medvedeva // International Journal of Engineering and Applied Sciences. - 2017. - Vol. 4, № 3. - P. 22.

37. Defects in structure as the sources of the surface charges of kaolinite / Xiaoyan Zhu, Zhichao Zhu, Xinrong Lei, Chunjie Yan // Applied Clay Science. - 2016. Vol. 124-125. - P. 127-136. DOI: 10.1016/j.clay.2016.01.033

38. Шлыков В.Г. Рентгеноструктурный анализ минерального состава дисперсного грунта. - М.: Геос, 2006. - 176 с.

38. Шлыков В.Г. Рентгеноструктурный анализ минерального состава дисперсного грунта. - М.: Геос, $2006 .-176$ с.
39. Шлыков В.Г. Использование структурных характеристик глинистых минералов для оценки физико-химических свойств дисперсных грунтов // Геоэкология. - 2000. - № 1. - С. 43-52.

40. Середин В.В., Красильников П.А., Медведева Н.А. Изменение электрокинетического потенциала глинистых коллоидов в водной и углеводородной средах // Геоэкология. Инженерная геология, гидрогеология, геокриология. - 2017. - № 1. - С. 66-74.

41. Изучение свойств глинистых пород при разработке соляных месторождений // В.В. Середин, Н.А. Медведева, Ю.О. Мальгина, Т.А. Пешкова // Современные технологии в строительстве. Теория и практика. - 2016. - Т. 2. - С. 451-454.

42. Тарасевич Ю.И., Овчаренко Ф.Д. Адсорбция на глинистых минералах. - Киев: Наукова думка, 1975. - 351 с.

43. Characterization and differentiation of kaolinites from selected Czech deposits using infrared spectroscopy and differential thermal analysis / L. Vaculíkova, E. Plevová, S. Vallová, I. Koutník // Acta Geodynamica et Geomaterialia. - 2011. - Vol. 8, № 1. - P. 59-67.

44. Laita E., Bauluz B. Mineral and textural transformations in aluminium-rich clays during ceramic firing // Applied Clay Science. - 2018. - Vol. 152. - P. 284-294. DOI: $10.1016 / \mathrm{j}$.clay.2017.11.025

45. Effect of thermochemical activation of clay raw materials on phase formation, microstructure and properties of aluminosilicate proppants / T.V. Vakalova, A.A. Reshetova, I.B. Revva, P.G. Rusinov, D.I. Balamygin // Applied Clay Science. - 2019. - Vol. 183. - P. 105335. DOI: 10.1016/j.clay.2019.105335

46. Sruthi P.L., Reddy P.H. Swelling and mineralogical characteristics of alkali-transformed kaolinitic clays // Applied clay science. - 2019. - Vol. 183. - P. 105353. DOI: 10.1016/j.clay.2019.105353 